\title{
Targeting neurotensin as a potential novel approach for the treatment of autism
}

\author{
Ahmad Ghanizadeh ${ }^{1,2}$
}

\begin{abstract}
The pathophysiology of autism remains obscure. Recently, serum neurotensin levels in children with autistic disorder have been found to be higher than those of normal children. Neurotensin is known to intensify neuronal NMDA-mediated glutamate signaling, which may cause apoptosis in autism. Further, an imbalance of glutamate/ GABAergic system in autism has been described. These observations lead to a postulate that neurotensin may accentuate the hyperglutaminergic state in autism, leading to apoptosis. Targeting neurotensin might be a possible novel approach for the treatment of autism.
\end{abstract}

A recently published study in Journal of Neuroinflammation reports the finding that neurotensin (NT) is elevated in the serum of young children with autistic disorder [1]. In cultured rat cortical neurons, NT has been shown to increase glutamate outflow and to intensify N-methyl D-aspartic acid- (NMDA-) mediated glutamate signaling [2]. In addition, NT may enhance glutamate transmission and, in particular, activate NMDA receptors [3,4]. Such overstimulation of NMDA glutamate receptors can lead to excitotoxicity [5]. Thus, factors that modulate glutamatergic transmission may affect glutamate-induced cell apoptosis.

Previous studies have suggested a possible role for a hyperglutaminergic state in autism [6]. Further, an antagonist of the NMDA glutamate receptor, memantine, has been shown to improve some symptoms in autism [7]. In contrast, there have been conflicting reports regarding the effects of NT on GABAergic synapses. At least one study has reported that NT inhibits GABAergic synaptic transmission in rats [8]. Other studies have indicated that NT enhances GABA release [9], activates GABAergic interneurons in rat prefrontal cortex [10], and increases GABAergic activity in rat hippocampus [11]. NT may act in the CNS as an atypical neuroleptic [12]. Studies using an antagonist of the NT receptor subtype 1 (NTS1) have elucidated the functions driven by this receptor [13], and antagonism of NTS1

\footnotetext{
Correspondence: ghanizadeha@hotmail.com

'Research Center for Psychiatry and Behavioral Sciences, Shiraz University of Medical Sciences, Hafez Hospital, Shiraz, Iran

Full list of author information is available at the end of the article
}

has been suggested as a novel therapeutic approach for the treatment of Parkinson's disease [4].

The higher serum levels of NT in young patients with autistic disorder does not necessarily indicate a casual role in autism [1]. Elevated NT levels in autistic disorder could be a result of inflammation. However, considering the known imbalance in glutamate-to-GABA ratios in children with autism [14], the higher levels of glutamate in autism [14], the downregulation of GABA(A) receptors in autism [15], and the role of NT in excessive activation of the NMDA receptor and apoptosis [3,4], NT may mediate brain damage in addition to activating inflammatory processes in autism. These observations collectively suggest a hypothesis that modulation of NT or of its receptors, in combination with traditional drugs, may provide a novel approach for the management of autism.

\section{Author details}

${ }^{1}$ Research Center for Psychiatry and Behavioral Sciences, Shiraz University of Medical Sciences, Hafez Hospital, Shiraz, Iran. ${ }^{2}$ Department of Psychiatry, Shiraz University of Medical Sciences, Hafez Hospital, Shiraz, Iran.

\section{Competing interests}

The author declares that they have no competing interests.

Received: 31 August 2010 Accepted: 1 October 2010 Published: 1 October 2010

\section{References}

1. Angelidou A, Francis K, Vasiadi M, Alysandratos KD, Zhang B, Theoharides $A$, Lykouras L, Sideri K, Kalogeromitros D, Theoharides TC: Neurotensin is increased in serum of young children with autistic disorder. $J$ Neuroinflammation 7(1):48. 
2. Antonelli T, Ferraro L, Fuxe K, Finetti S, Fournier J, Tanganelli S, De Mattei M, Tomasini MC: Neurotensin enhances endogenous extracellular glutamate levels in primary cultures of rat cortical neurons: involvement of neurotensin receptor in NMDA induced excitotoxicity. Cereb Cortex 2004, 14(4):466-473.

3. Ferraro L, Tomasini MC, Mazza R, Fuxe K, Fournier J, Tanganelli S, Antonelli T: Neurotensin receptors as modulators of glutamatergic transmission. Brain Res Rev 2008, 58(2):365-373.

4. Antonelli T, Fuxe K, Tomasini MC, Mazzoni E, Agnati LF, Tanganelli S, Ferraro $L$ : Neurotensin receptor mechanisms and its modulation of glutamate transmission in the brain: relevance for neurodegenerative diseases and their treatment. Prog Neurobiol 2007, 83(2):92-109.

5. Liu Z, Qiu YH, Li B, Ma SH, Peng YP: Neuroprotection of Interleukin-6 Against NMDA-Induced Apoptosis and Its Signal-Transduction Mechanisms. Neurotox Res.

6. Shinohe A, Hashimoto K, Nakamura K, Tsujii M, Iwata Y, Tsuchiya KJ, Sekine Y, Suda S, Suzuki K, Sugihara G, et al: Increased serum levels of glutamate in adult patients with autism. Prog Neuropsychopharmacol Biol Psychiatry 2006, 30(8):1472-1477.

7. Chez MG, Burton Q, Dowling T, Chang M, Khanna P, Kramer C: Memantine as adjunctive therapy in children diagnosed with autistic spectrum disorders: an observation of initial clinical response and maintenance tolerability. J Child Neurol 2007, 22(5):574-579.

8. Mitchell VA, Kawahara H, Vaughan CW: Neurotensin inhibition of GABAergic transmission via mGluR-induced endocannabinoid signalling in rat periaqueductal grey. J Physiol 2009, 587(Pt 11):2511-2520.

9. Petkova-Kirova P, Rakovska A, Della Corte L, Zaekova G, Radomirov R, Mayer A: Neurotensin modulation of acetylcholine, GABA, and aspartate release from rat prefrontal cortex studied in vivo with microdialysis. Brain Res Bull 2008, 77(2-3):129-135.

10. Petrie KA, Schmidt D, Bubser M, Fadel J, Carraway RE, Deutch AY: Neurotensin activates GABAergic interneurons in the prefrontal cortex. J Neurosci 2005, 25(7):1629-1636.

11. Li S, Geiger JD, Lei S: Neurotensin enhances GABAergic activity in rat hippocampus $C A 1$ region by modulating L-type calcium channels. J Neurophysiol 2008, 99(5):2134-2143.

12. Jolicoeur FB, Gagne MA, Rivest R, Drumheller A, St-Pierre S: Atypical neuroleptic-like behavioral effects of neurotensin. Brain Res Bull 1993, 32(5):487-491.

13. Rostene W, Azzi M, Boudin H, Lepee I, Souaze F, Mendez-Ubach M, Betancur C, Gully D: Use of nonpeptide antagonists to explore the physiological roles of neurotensin. Focus on brain neurotensin/ dopamine interactions. Ann N Y Acad Sci 1997, 814:125-141.

14. Harada M, Taki MM, Nose A, Kubo H, Mori K, Nishitani H, Matsuda T: NonInvasive Evaluation of the GABAergic/Glutamatergic System in Autistic Patients Observed by MEGA-Editing Proton MR Spectroscopy Using a Clinical 3 Tesla Instrument. J Autism Dev Disord 2010, ePub.

15. Fatemi SH, Reutiman TJ, Folsom TD, Thuras PD: GABA(A) receptor downregulation in brains of subjects with autism. J Autism Dev Disord 2009, 39(2):223-230

doi:10.1186/1742-2094-7-58

Cite this article as: Ghanizadeh: Targeting neurotensin as a potential novel approach for the treatment of autism. Journal of Neuroinflammation 2010 7:58.

\section{Submit your next manuscript to BioMed Central and take full advantage of:}

- Convenient online submission

- Thorough peer review

- No space constraints or color figure charges

- Immediate publication on acceptance

- Inclusion in PubMed, CAS, Scopus and Google Scholar

- Research which is freely available for redistribution

Submit your manuscript at www.biomedcentral.com/submit 